\title{
SIMPLE REPORTING TRAINING AND INTRODUCTION OF SAK EMKM TO SMES IN BANYURESMI VILLAGE IN PREPARATION FOR THE PANDEGLANG TOURISM VILLAGE
}

\author{
Verliani DASMARAN ${ }^{1 *}$, Sanusi SANUSI ${ }^{2}$, Hendi PRIHANTO ${ }^{3}$, and Irma Paramita SOFIA ${ }^{4}$ \\ 1,2 Mathlaul Anwar Universitity \\ ${ }^{3}$ Prof. Dr. Moestopo (Beragama) Universitity \\ ${ }^{4}$ Pembangunan Jaya University \\ *eeytea@gmail.com; se.sanusi@gmail.com; hendiprihanto@dsn.moestopo.ac.id; irma.paramita@upj.ac.id
}

\begin{abstract}
The purpose of the simple reporting training and introduction of SAK EMKM to SMEs in Banyuresmi Village. Is to provide knowledge and facilitate the preparation of simple reports so that businesses can be funded by third parties because financial reports show the accountability of these SMEs. The training method applied is face-to-face, and direct training by being given a financial report form with SAK EMKM standard. Direct guidance to 40 SMEs participants by means of 2 sessions to avoid participants being too crowded. The results of the service are expected that all SMEs in Banyuresmi Village who take part in the training have accountable records and reports that can be used in all administrative processes including funding by third parties such as banking and others.
\end{abstract}

\section{Keywords: Simple Reporting, SAK EMKM}

\section{BACKGROUND}

According to legislation No. 20 of 2008 explains that SMEs are productive businesses owned by individuals or business entities that have met the criteria as microenterprises. In Indonesia, SMEs are recorded as informal micro-enterprises, both those who are self-employed without the assistance of workers or assisted by temporary workers, in 2020, an increase of 1.18 million people (2.62 percent) from 45.07 million people in 2019 to 46.25 million people in 2020. 2020 data from the Ministry of Cooperatives and SMEs (https://kemenkopukm.go.id/).

The data above shows that the number of SMEs in Indonesia is very large and really supports the progress of the nation's economy, so the existence and sustainability of these SMEs activities need to be maintained and improved so as to form a financially strong society (Suci, 2017). This simple financial reporting training was carried out in the village of Banyuresmi, which is a village in the Pandeglang and includes a tourist village https://bingar.id/ wisata-murah-di-kampung-bambu-pandeglang/.

A tourism village is the development of a village area which basically does not change what already exists but tends to develop the potential of the existing village by utilizing the capabilities of the elements that exist in the village which function as attributes of tourism products on a small scale into a series of activities. tourism activities or activities and is able to provide and fulfill a series of travel needs both in terms of attractiveness and as supporting facilities (Hermawan, 2017).

Banyuresmi village is a village in the Pandeglang area, precisely in the District of Jiput. The geographical location of Banyuresmi village is located between the north, Jiput village in the south, Cikedal sub-district, in the west, Sukacai village, in the east, Salapraya village. Banyuremi Village is a productive village in agriculture, because Jiput is a rice-producing center in the Pandeglang region (BPS, 2017). The Banyuresmi village community has several unique products that have selling power that can increase regional income. The products produced from jiput range from rice, coconut, melinjo, corn, secondary crops, cassava and others. For more details, the official banyu map can be seen in Figure 1.

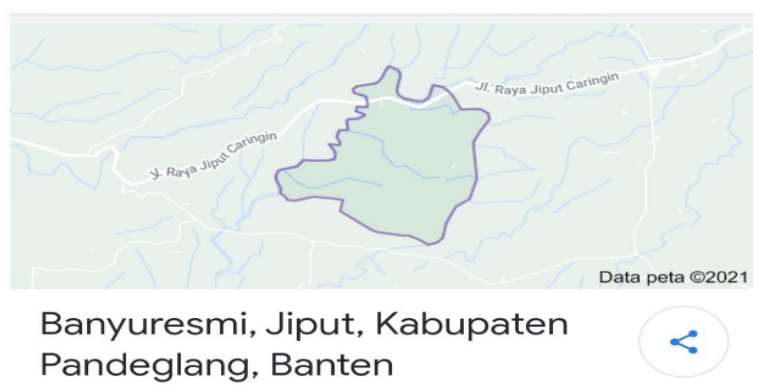

Figure 1. Map Banyuresmi Village

Banyuresmi Village in addition to producing secondary crops from plantations and rice fields that can be produced, Banyuresmi village is one of the tourist villages, namely bamboo village tourism https:/bingar.id/wisatamurah-di-kampung-bambu-pandeglang/. This makes the great potential for SMEs in the Banyuresmi village to progress rapidly as a support for the progress of the tourist village. So this is an attraction for SMEs to make their business wider and business continuity can be guaranteed by prioritizing accountability so that investors can come and be interested in funding (Rudiantoro \& Siregar, 2012). This encourages the implementation of simple reporting training and the introduction of SAK EMKM so that SMEs are ready to create tourist villages that are more attractive and can increase people's income and in general will increase PAD (Regional Original Income).

\section{METHOD}

The method used in this service activity is the face-toface training method. Even during the COVID-19 pandemic, the community, namely SMEs, was very enthusiastic about participating in training activities. The training is carried out by implementing strict health protocols so as to minimize the occurrence of unwanted things. 
The protocols implemented consist of maintaining a distance between training participants, measuring participants' body temperatures and ensuring they are in good health, providing hand sanitizer, hand washing facilities and all participants are required to wash their hands before entering. Face-to-face training had to be carried out for several reasons, first, in Banyuresmi village, internet signal was still difficult so that zoom was not possible, secondly, the human resources of SMEs actors were not familiar with zoom applications and the like. But what strengthens the implementation of faceto-face training is the lack of public trust in the Covid-19 problem so that they do not question the face-to-face implementation technique.

The limited space for the village participants was divided into two teams, each team of 20 SMEs actors. The activity was assisted by 5 students who directed how SMEs reporting practices could be controlled and distributed the prepared report formats.

Materials provided

1. Explanation of SAK SMEs that can be made by participants for internal and external purposes so that participants know the functions and uses of SAK SME sreports.

2. Introducing what reports must be owned by participants as SMEs actors

3. To record and allocate transactions that often occur in the business activities of SMEs actors

4. To record the sources of income owned by each actor and record on the practice sheet that has been prepared by the service team

5. List the costs that must be incurred from each participant and record in the prepared report format

6. Calculate the turnover, profit and tax of each SMEs actor so that all SMEs already have an income statement in accordance with the SMEs SAK

7. Calculating financial position reports by helping participants record assets and forests owned so that they can prepare for the next period

8. Introducing notes to financial statements, but this cannot be made optimally because it still takes time and a deeper understanding.

\section{Result And Discussion}

The results of the simple reporting training and introduction to SAK EMKM were carried out in August for 2 days on 30 to 31 August to be exact Monday and Tuesday with a duration of three hours per team, team 1 started from 09.00 to 12.00 , while team 2 started from 13.00 to 16.00 .

The enthusiasm of the participants in teams 1 and 2 of 20 people each so that the total number of 40 participants was very visible with the enthusiasm to create and learn how to record all transactions, and make them into a financial report.

If you analyze the SWOT condition of SMEs in the Banyuresmi area.

\begin{tabular}{|c|c|}
\hline $\begin{array}{l}\text { Strengths } \\
\text { - Cool and fertile natural } \\
\text { conditions are able to produce } \\
\text { quality commodities } \\
\text { - Willingness of the community } \\
\text { to explore business potential in } \\
\text { obtaining income }\end{array}$ & $\begin{array}{l}\text { Weakness } \\
\text { - There is still a lack of internet } \\
\text { connection so that marketing } \\
\text { information is hampered } \\
\text { - The products produced are } \\
\text { relatively the same so that the } \\
\text { competition is quite visible }\end{array}$ \\
\hline $\begin{array}{l}\text { Oportunities } \\
\text { - Abundant product raw } \\
\text { materials so that business } \\
\text { continuity is safe } \\
\text { - Geographical location is not } \\
\text { too far from the city center, } \\
\text { about } 3 \text { hours with good road } \\
\text { access, which makes the } \\
\text { distribution system easy } \\
\text { - The availability of an } \\
\text { expedition system makes it } \\
\text { easier for the delivery system }\end{array}$ & $\begin{array}{l}\text { Threat } \\
\text { - Similar products make } \\
\text { competition less good } \\
\text { - There is still an old- } \\
\text { fashioned mindset in society } \\
\text { that hinders progress }\end{array}$ \\
\hline
\end{tabular}

The forms prepared by the community service team are the income statement form, the financial position report form and notes to the financial statements. At the beginning, participants record transactions that usually occur and are clerical in nature. Daily notes are the basis for making simple reports.

The final result of this simple reporting training is that each participant has records that describe daily transactions resulting from product sales, training participants have financial reports according to SAK EMKM so that in the future the participants can make their own reports. However, if there are obstacles, the community service team is willing to assist in making reports so that reporting can be used optimally. Here I send photos of simple reporting training activities and the introduction of SAK EMKM in Figure 2 below

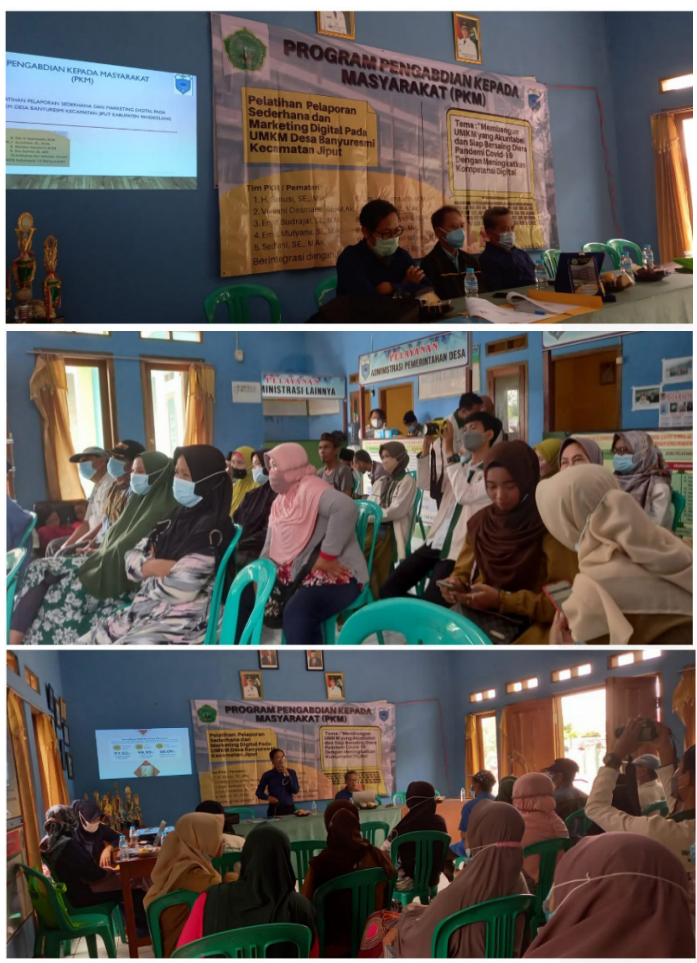

Figure 2. Photo of Simple Reporting Training Activities for MSMEs in Banyuresmi Village 


\section{CONCLUSION}

Simple reporting training activities have the aim of providing knowledge for SMEs in Banyuresmi village to prepare SMEs that are ready to support tourist villages, so as to achieve community welfare and increase PAD (Regional Original Income). The method used is a method of direct assistance to 40 SMEs participants with technically divided into two teams, so each team is twenty. Because the training was carried out during the Covid-19 period, the implementation was carried out by implementing strict health protocols. The results of the SMEs analysis in Banyuresmi Village can be analyzed with a swot analysis with the aim of making it easier to map out the problems that will be faced by SMEs. The final product of the training is that each participant has a simple financial report that is in accordance with SAK EMKM and can be used as a form of company accountability in submitting capital applications to third parties.

\section{ACKNOWLEDGEMENT}

Community Service Team Faculty of Economics and Business Mathlaul Anwar University Banten and Prof. University Dr. Moestopo (Religious), expressed the highest appreciation to all those who have provided assistance for this activity, namely: (1) Chancellor of Mathlaul Anwar University Banten (2) Chancellor of the University of Prof. Dr. Moestopo (Religious), (3) Chancellor of Pembangunan Jaya University (4)Research and Community Service Institute,Mathlaul Anwar University Banten,(5) Research and Community Service Institute, Prof. University Dr. Moestopo (Religious), (6) Research and Community Service Institute, Pembangunan jaya University.(7) Dean of the Faculty of Economics and Business Mathlaul Anwar University Banten (8) Dean of the Faculty of Economics and Business University of Prof. Dr. Moestopo (Religious), (9) Dean of the Faculty of Humanities and Business of Pembangunan Jaya University (10) Head of Banyu resmi
Village, Jiput District, Pandeglang Regency, Banten and their staff, (11) Groups XV 2021 KKN Mathlaul Anwar University Banten

\section{REFERENCE}

https://bingar.id/wisata-murah-di-kampung-bambupandeglang/

https://kemenkopukm.go.id/

Hermawan, H. (2017). Dampak Pengembangan Desa Wisata Nglanggeran Terhadap Ekonomi Masyarakat Lokal, III(2), 105-117. https://doi.org/10.31219/osf. io/xhkwv

Maseko, N. and O. Manyani. 2011. Accounting Practices of SMEs in Zimbabwe: An Investigative Study of Record Keeping for Performance Measurement (A Case Study of Bindura). Journal of Accounting and Taxation, 3 (8), 171-18

Pinasti, M. 2001. Penggunaan Informasi Akuntansi dalam Pengelolaan Usaha Para Pedagang Kecil di Pasar Tradisional Kabupaten Banyumas. Jurnal Ekonomi, Bisnis, dan Akuntansi, 1 (3)

Rudiantoro, R., \& Siregar, S. V. (2012). Kualitas Laporan Keuangan Umkm Serta Prospek Implementasi Sak Etap. Jurnal Akuntansi Dan Keuangan Indonesia, 9(1), 1-21. https://doi.org/10.21002/jaki.2012.01

Suci, Y. R., Tinggi, S., \& Ekonomi, I. (2017). Perkembangan UMKM (Usaha Mikro Kecil Menengah) di Indonesia. Jurnal Ilmiah Fakultasi Ekonomi.

Warsono, S. dan E. Murti. 2010. Akuntansi UMKM Ternyata Mudah Dipahami dan Dipraktikkan. Yogyakarta: Asgard Chapter Winarno.

Zimele, A. 2009. The SMME Business Toolkit. New York: SBDA(Pty) Ltd 